\title{
WHITMAN: A CURRENT BIBLIOGRAPHY
}

Booth, Martin. "Walt Whitman's Soldier Boy." West Hills Review 8 (1988), 11. [Poem.]

Broderick, Charles C. "Charles E. Feinberg Dies, Was Library Benefactor." Library of Congress Information Bulletin 49 (9 May 1988), 194-195.

Brown, Susan Margaret. "The Poetics of Pessoa's Drama em Gente: The Function of Alberto Caeiro and the Role of Walt Whitman." Ph.D. Dissertation, University of North Carolina at Chapel Hill, 1987. [DAI 48 (January 1988), 1761A.]

Cumming, Mark. Review of George B. Hutchinson, The Ecstatic Whitman. Canadian Review of American Studies 18 (Summer 1987), 299-300.

Ellman, Richard. “Oscar Meets Walt.” New York Review of Books 34 (3 December 1987), 43-44.

Everett, Graham. "A Reading of Walt Whitman's 'Give Me the Splendid Silent Sun.'" West Hills Review 8 (1988), 105-111.

Fahey, W. A., ed. West Hills Review: A Walt Whitman fournal, 8 (1988). [Contains five line drawings of Whitman by Alfred Van Loen, fifty-four poems, and six essays; the poems and essays dealing with Whitman are listed separately in this bibliography.]

Feinberg, Charles E. “Charles Feinberg on Whitman." Walt Whitman Quarterly Review 6 (Summer 1988), 55-56.

Fichtelberg, Joseph Alan. "The Complex Image: IFaith and Method in American Autobiography." Ph.D. Dissertation, Columbia University, 1987. [DAI 48 (February 1988), 2061A. Discusses process of revision in Specimen Days.]

Folsom, Ed, ed. "Charles E. Feinberg: A Tribute." Walt Whitman Quarterly Review 6 (Summer 1988), 39-56. [Contains recollections of and tributes to Charles Feinberg by Gay Wilson Allen, Roger Asselineau, Ed Folsom, Arthur Golden, C. Carroll Hollis, Jerome Loving, Edwin Haviland Miller, and William White; and excerpts of Feinberg's writings on Whitman.]

Gelpi, Albert. "The Poetics of Open Form: The Mixed Message of Whitman and Williams." In Beverley Taylor and Robert Bain, eds., The Cast of Consciousness: Concepts of the Mind in British and American Romanticism. New York: Greenwood, 1987, pp. 201-214.

Hindus, Milton. Essays: Personal and Impersonal. Santa Rosa: Black Sparrow, 1988. [Reprints, on pp. 59-78, "Walt Whitman: Critical Reception from 1855 to the Present," from Hindus, ed., Walt Whitman: The Critical Heritage (1971).]

Hollis, C. Carroll. "Recasting Leaves of Grass: Whitman's Moral Vocabulary in the Early and Late Poems." In Beverley Taylor and Robert Bain, eds., The Cast of Consciousness: Concepts of the Mind in British and American Romanticism. New York: Greenwood, 1987, pp. 173-200. [On Whitman's changing uses of the words spiritual, religious, conscience, moral.] 
- "Recollections of Charles Feinberg." Walt Whitman Quarterly Review 6 (Summer 1988), 47-54.

Hooker, Jeremy. Review of M. Wynn Thomas, The Lunar Light of Whitman's Poetry. Anglo-Welsh Review 87 (1987), 142-144.

Hughes, James M. "Whitman and Longfellow: The Breaking Up of Vessels." West Hills Review 8 (1988), 63-69.

Hutchinson, George B. "Life Review and the Common World in Whitman's Specimen Days." South Atlantic Review 52 (Autumn 1987), 3-23.

Kummings, Donald D. Review of Edwin H. Cady and Louis J. Budd, eds., On Whitman: The Best from American Literature. Walt Whitman Quarterly Review 6 (Summer 1988), 33-35.

Leonard, Gay Lynne. "Poetic Ingress: A Study of Opening Lines in Whitman, Dickinson, and Lanier." Ph.D. Dissertation, University of Tulsa, 1987. [DAI 48 (August 1987), 390A.]

Mann, C. Review of Ed Folsom, ed., This Heart's Geography's Map: Photographs of Walt Whitman [special issue of Walt Whitman Quarterly Review 4 (Fall/Winter 1986-87)]. History of Photography 12 (January-March 1988), 83.

Mills, A. R. "Dear friend ... Love and Walt Whitman." West Hills Review 8 (1988), 25-32. [On Whitman and Anne Gilchrist.]

Moder, Donna. "Gender Bipolarity and the Metaphorical Dimensions of Creativity in Whitman's Poetry: A Psychobiographical Study." Literature and Psychology 34 (1988), 34-52.

Murphy, Francis. Review of Thomas, Lunar Light of Whitman's Poetry. Essays in Criticism 37 (July 1987), 257-264:

Murphy, Kevin. "Walt Whitman and Louis Sullivan: The Aesthetics of Egalitarianism." Walt Whitman Quarterly Review 6 (Summer 1988), 1-15.

Nahal, Chaman. "Walt Whitman and the Evolution of the Spirit." West Hills Review 8 (1988), 1-9.

Peters, Robert. Review of Charley Shively, ed., Calamus Lovers. American Book Review 9 (January/February 1988), 22.

Roche, John F. "Democratic Space: The Ecstatic Geography of Walt Whitman and Frank Lloyd Wright." Walt Whitman Quarterly Review 6 (Summer 1988), 16-32.

_. "Walt Whitman's 'Manahatta' [sic] and Frank Lloyd Wright's 'Broadacre City': Concurrent Envisionings of a Democratic City." Ph.D. Dissertation, State University of New York at Buffalo, 1987. [DAI 48 (August 1987), 391A.]

Singer, Ben. "Connoisseurs of Chaos: Whitman, Vertov and the Poetic-Survey." Literature/Film Quarterly 15(1987), 247-258. [On Whitman's affinity with Dziga Vertov, whose The Man With the Movie Camera is seen as "a virtually diagrammatic representation of the dominant Soviet perspective on Whitman."] 
Slatoff, Walter J. The Look of Distance: Reflections on Suffering and Sympathy in Modern Literature-Auden to Agee, Whitman to Woolf. Columbus: Ohio State University Press, 1985. [Chapter 6, "The Engulfings of Others and Delicious Unions with Death," pp. 133-153, focuses on Whitman.]

Tapscott, Stephen. Review of Thomas, Lunar Light of Whitman's Poetry. American Literature 59 (December 1987), 659-661.

White, Claire Nicolas. "The Road to Whitman." West Hills Review 8 (1988), 47-50. [Personal testimonial of Whitman's influence.]

Wormser, Baron. "Homage to Thomas Eakins." Manhattan Review 4 (Fall 1986), 10. [Poem.]

The University of Iowa

ED FoLsOM 